\title{
Experimental determination of the heterotroph anoxic yield in anoxic-aerobic activated sludge systems treating municipal wastewater
}

\author{
AW Muller ${ }^{1}$, MC Wentzel ${ }^{1 *}$ and GA Ekama ${ }^{1}$ \\ ${ }^{1}$ Water Research Group, Department of Civil Engineering, University of Cape Town, Rondebosch 7701, South Africa
}

\begin{abstract}
This paper describes experimental research to directly quantify the ordinary heterotrophic organism (OHO) cell yield coefficient under anoxic and aerobic conditions with real wastewater as substrate. Until recently these two values were assumed equal in activated sludge models, despite theoretical predictions that the anoxic yield should be reduced relative to its aerobic value. In this study, parallel aerobic and anoxic batch tests were conducted on the same mixtures of wastewater and mixed liquor drawn from anoxic-aerobic activated sludge systems. By equating the readily biodegradable (RB)COD concentrations in the aerobic and anoxic batch tests, the anoxic yield was determined in terms of the respective measured oxygen and nitrate utilisations and the aerobic yield. Additionally, the aerobic and anoxic yield coefficients were directly determined by using defined quantities of the artificial RBCOD acetate. The wastewater batch tests demonstrated that the OHO anoxic yield is reduced to approximately $81 \%$ $(0.54)$ of the aerobic value $(0.67 \mathrm{mgCOD} / \mathrm{mgCOD})$. The anoxic:aerobic yield ratio $(0.81)$ was confirmed independently in the acetate batch tests at 0.84 , and closely equals that predicted theoretically from thermodynamic and bioenergetic principles $(0.83)$. From these investigations, it is recommended that the $\mathrm{OHO}$ anoxic yield be decreased to 0.54 for an aerobic yield value of 0.67 $\mathrm{mgCOD} / \mathrm{mgCOD}$.
\end{abstract}

\section{Introduction}

Integral to the biological nutrient removal (BNR) activated sludge system is the biologically mediated process of denitrification. Accordingly, biological denitrification has been explicitly incorporated into the steady-state design (e.g. WRC, 1984; Wentzel et al., 1990) and kinetic simulation (e.g. Van Haandel et al., 1981; Henze et al., 1987; Dold et al., 1980, 1991; Gujer et al., 1999) models developed as aids to the design and operation of BNR activated sludge systems. In both sets of models, critical as input to quantify the denitrification is the value for the ordinary heterotrophic organism $(\mathrm{OHO})$ cell yield coefficient under anoxic conditions $\left(\mathrm{Y}_{\mathrm{H}, \mathrm{NO}}\right)$. In terms of the models, the heterotrophic cell yield coefficient, $\mathrm{Y}_{\mathrm{H}}$, (designated here $\mathrm{Y}_{\mathrm{H}, \mathrm{NO}}$ for anoxic conditions and $\mathrm{Y}_{\mathrm{H}, \mathrm{AE}}$ for aerobic) determines both the mass of electron acceptor utilised and the new cell biomass produced. In activated sludge systems treating municipal wastewaters, the effect of $\mathrm{Y}_{\mathrm{H}, \mathrm{NO}}$ on sludge production typically is small, since the mass of sludge produced under anoxic conditions is small compared with that produced under aerobic conditions, due to the relatively low influent TKN/COD ratios (Barker and Dold, 1997). In contrast, the effect of $\mathrm{Y}_{\mathrm{H}, \mathrm{NO}}$ on the amount of denitrification achievable (and hence, on system design and operation) is quite significant.

In the IWA Task Group models for activated sludge systems, ASM1 (Henze et al., 1987), ASM2 (Henze et al., 1995) and ASM2d (Henze et al., 1999), and similar (e.g. Dold et al., 1991; Wentzel et al., 1992), $\mathrm{Y}_{\mathrm{H}}$ is assumed to have the same value under anoxic as under aerobic conditions. However, when nitrate serves

This paper was originally presented at the 2004 Water Institute of South Africa (WISA) Biennial Conference, Cape Town, South Africa, 2-6 May 2004.

* To whom all correspondence should be addressed.

푱+2721 6502583; fax:+2721 6897471; e-mail: markw@eng.uct.ac.za as terminal electron acceptor, ideally only 2 ATP are formed per pair of electrons (e-) transferred to nitrate compared with 3 ATP when the transfer is to oxygen (Payne, 1981; WRC, 1984; Kuba et al., 1993; Casey et al., 1999; Wentzel et al., 2003). This difference reduces the energy captured by the organism when nitrate serves as electron acceptor (versus oxygen) in biological oxidation of organic substrate. Correspondingly, therefore, the cell yield under anoxic conditions $\left(\mathrm{Y}_{\mathrm{H}, \mathrm{NO}}\right)$ should be reduced relative to its aerobic value $\left(\mathrm{Y}_{\mathrm{H}, \mathrm{AE}}\right)$.

Based on bioenergetic principles set out by McCarty (1971, 1972, 1975), Orhon et al. (1996) theoretically quantified the anoxic to aerobic yield ratio for four organic substrates, municipal wastewater, protein, lactate and carbohydrate, and obtained respective anoxic:aerobic yield ratios of: $0.79,0.80,0.80$, and 0.85 . Accepting the standard aerobic heterotrophic yield value of 0.67 $\mathrm{mgCOD} / \mathrm{mgCOD}$ used in ASM1 and similar models, this gives an anoxic yield of $0.53 \mathrm{mgCOD} / \mathrm{mgCOD}$ for municipal-type wastewaters as substrate. Similarly, based on thermodynamic and bioenergetic principles, Muller et al. (2003a) showed that theoretically the anoxic cell yield coefficient $\left(\mathrm{Y}_{\mathrm{H}, \mathrm{NO}}\right)$ is about $83 \%$ of its aerobic value $\left(\mathrm{Y}_{\mathrm{H}, \mathrm{AE}}\right)$.

Although limited, several studies reported in the literature (reviewed by Muller et al., 2003a) provide direct and indirect experimental evidence supporting the theoretical assessment that the anoxic cell yield should be reduced relative to its aerobic counterpart. For these studies an average anoxic:aerobic cell yield ratio was calculated as $0.81 \pm 0.035$, or about $0.54 \mathrm{mgCOD} /$ mgCOD (range $0.52-0.57$ ) with respect to the standard aerobic yield of $0.67 \mathrm{mgCOD} / \mathrm{mgCOD}$ (Muller et al., 2003a) (The \pm symbol denotes standard deviation throughout the paper except where indicated otherwise). This substantiates the theoretical evaluations above that the anoxic yield should be reduced relative to its aerobic value.

While a reduced heterotrophic yield under anoxic conditions is apparent from bioenergetic theory and supported by experimental 
evidence in the literature, direct substantiation with real municipal sewage is lacking. Most of the studies in the literature reviewed by Muller et al. (2003a) were performed with defined substrates, hydrolysates, and/or mixtures of various domestic and industrial wastewaters, and focused mainly on estimating specific denitrification rates. Consequently, few provide information directly relating nitrate and corresponding substrate utilisations necessary to estimate the yield. Furthermore, some studies were performed with mixed polyphosphate accumulating organism (PAO) sludges from nitrification-denitrification biological excess phosphorous removal (NDBEPR) activated sludge systems, which introduces unquantifiable uncertainty into observed yield measurements (Barker and Dold, 1996; Hu et al., 2000, 2002). Accordingly, a research project was undertaken to quantify the $\mathrm{OHO}$ cell yield under anoxic conditions relative to its value under aerobic conditions with municipal sewage as substrate, and is summarised in the paper (for details, see Muller et al., 2003a).

\section{Research approach}

In the research approach adopted for this study, it was recognised that the equations quantifying the concentration of soluble substrate utilised in aerobic and anoxic respiration (in terms of the cell yield and electron acceptor utilisation) could be equated if the respective soluble substrate concentrations utilised are the same. Thus, if the oxygen and nitrate utilised (OU and NU respectively) for the consumption of the same amount of readily biodegradable(RB)COD under respective aerobic and anoxic conditions can be quantified, then $\mathrm{Y}_{\mathrm{H}, \mathrm{NO}}$ can be determined as a function of $\mathrm{Y}_{\mathrm{H}, \mathrm{AE}}$; i.e.:

$$
\begin{aligned}
& \frac{\mathrm{OU}}{\left(1-\mathrm{Y}_{\mathrm{H}, \mathrm{AE}}\right)}=\mathrm{RBCOD} \equiv \mathrm{S}_{\mathrm{s}}=\frac{2.86 * \mathrm{NU}}{\left(1-\mathrm{Y}_{\mathrm{H}, \mathrm{NO}}\right)} \\
& \Rightarrow \mathrm{Y}_{\mathrm{H}, \mathrm{NO}}=1-\frac{2.86 * \mathrm{NU}}{\mathrm{OU}} *\left(1-\mathrm{Y}_{\mathrm{H}, \mathrm{AE}}\right)
\end{aligned}
$$

On this basis, anoxic and aerobic batch tests containing the same concentration of RBCOD and acclimatised mixed-liquor from the same source were performed, and the corresponding $\mathrm{OU}$ and $\mathrm{NU}$ (respectively) measured to determine estimates for $\mathrm{Y}_{\mathrm{H}, \mathrm{NO}}$ as a function of $\mathrm{Y}_{\mathrm{H}, \mathrm{AE}}$ via Eq. [2].

In this approach, since $\mathrm{OU}$ and $\mathrm{NU}$ are related to complete utilisation of RBCOD rather than its rate of utilisation (Ekama et al., 1986), exact definition of the OHO biomass in the batch tests is not essential. What is required is that the initial RBCOD concentration in the corresponding batch tests be the same and that all the RBCOD is utilised; this is evident from established discussions on loading rate effects in aerobic batch tests (e.g. Ekama et al., 1986; Dold et al., 1991; Wentzel et al., 1999). Furthermore, the difficulties and complications in measuring OHO denitrification and associated yields due to the presence of PAOs was recognised in this investigation. Accordingly, only sludges from $\mathrm{N}$ removal only (i.e. no BEPR) plants were used in the batch tests. Further, since RBCOD is eliminated as a variable by equating aerobic and anoxic respirometries (Eq. [1]), the concentration of RBCOD is not required to estimate $\mathrm{Y}_{\mathrm{H}, \mathrm{NO}}$, provided $\mathrm{Y}_{\mathrm{H}, \mathrm{AE}}$ is known. However, this requires that the standard $\mathrm{Y}_{\mathrm{H}, \mathrm{AE}}(0.67 \mathrm{mgCOD} / \mathrm{mgCOD})$ be accepted in this study. As an independent assessment of this value (and $\mathrm{Y}_{\mathrm{H}, \mathrm{NO}}$ estimates as well), yields were determined directly by adding known concentrations of the artificial RBCOD, acetate, to the batch tests, and monitoring OU and NU.

For a complete description of the research reported in this paper see Muller et al. (2003a).

\section{Aerobic and anoxic batch test method}

The wastewater used in this investigation was collected in batches from the Mitchells Plain Wastewater Treatment Plant (MPWWTP) approximately every 2 weeks and stored at $<4{ }^{\circ} \mathrm{C}$ in a cold room. The aerobic and anoxic batch tests were performed using this wastewater, and biomass obtained from laboratory-scale Modified Ludzack-Ettinger (MLE) systems fed with the same wastewater, as well as from the MPWWTP. In each batch test, defined volumes of the wastewater and mixed-liquor were combined in a continuously stirred batch reactor. In the aerobic batch tests (ABT), the oxygen utilisation rate (OUR) with time was measured automatically (Randall et al., 1991), while in the denitrification (anoxic) batch tests (DBT), the nitrate utilisation rate (NUR) was determined from the nitrate concentration versus time profile for samples drawn manually at specific time intervals during the test. Typical examples of OUR and NUR profiles obtained in aerobic and anoxic batch tests, respectively, are shown in Fig. 1.

Additionally, aerobic and anoxic batch tests were performed with addition of the defined RBCOD acetate to mixed liquors from the systems above.

\section{Batch test results}

The batch experiments were grouped into three chronological Periods, where "ABT" and "DBT" refer to "aerobic" and “denitrification” (or anoxic) "batch test”, respectively.

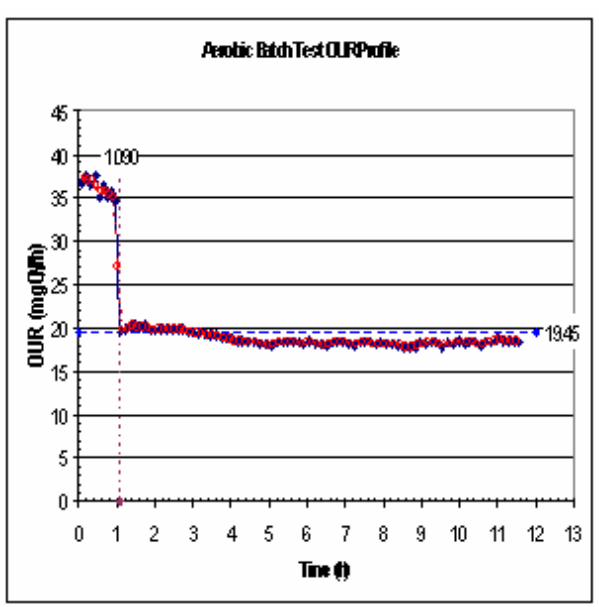

(a) Period I, ABT 14

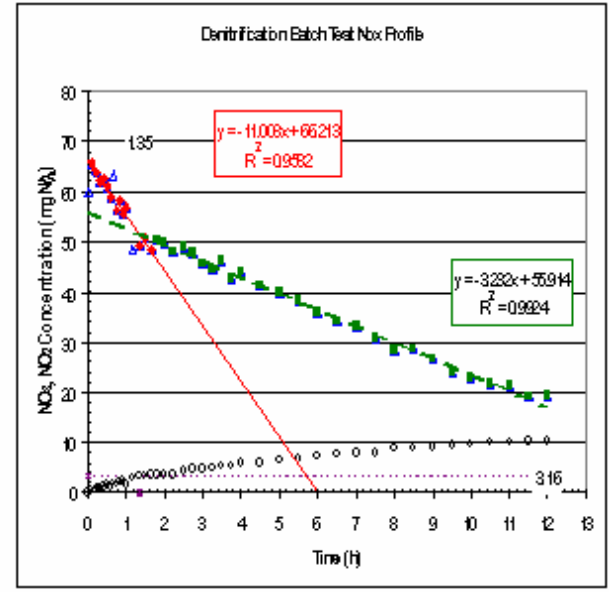

(b) Period I, DBT 14
Figure 1

Typical examples of (a) oxygen utilisation rate (OUR) and (b) nitrate utilisation rate (NUR) profiles obtained in parallel aerobic and anoxic batch test experiments, respectively 


\begin{tabular}{|l|c|c|c|}
\hline Period & Dates & ABT & DBT \\
\hline I & $17 / 1 / 02-4 / 6 / 02$ & $1-22$ & $1-19$ \\
II & $26 / 8 / 02-10 / 10 / 02$ & $23-34$ & $20-29$ \\
III & $11 / 10 / 02-16 / 12 / 02$ & $35-40$ & $30-42$ \\
\hline
\end{tabular}

\section{Period I: Estimation of $Y_{H, N O}$ in Terms of $Y_{H, A E}$ Using Wastewater RBCOD}

In Period I, aerobic and anoxic batch tests were performed in parallel with mixtures of the same volumes of wastewater and mixed-liquor, abstracted from the same batches of wastewater and activated sludge systems, respectively. From the OU and NU determined from the corresponding aerobic and anoxic batch tests, $\mathrm{Y}_{\mathrm{H}, \mathrm{NO}}$ values were estimated as a function of $\mathrm{Y}_{\mathrm{H}, \mathrm{AE}}$ (Eq. [2]). All the $\mathrm{Y}_{\mathrm{H}, \mathrm{NO}}$ estimates for $\mathrm{Y}_{\mathrm{H}, \mathrm{AE}}=0.67 \mathrm{mgCOD} / \mathrm{mgCOD}$ were evaluated for outliers and analysed statistically in a linearised probability graph (Fig. 2). No outliers were identified and the data exhibits a normal distribution, giving a mean $\mathrm{Y}_{\mathrm{HNO}}$ of $0.534 \pm 0.041$ (range 0.493 - 0.575), or equivalently an anoxic:aerobic yield ratio $\left(\mathrm{Y}_{\mathrm{H}, \mathrm{NO}}: \mathrm{Y}_{\mathrm{H}, \mathrm{AE}}\right)$ of 0.797 with respect to $\mathrm{Y}_{\mathrm{H}, \mathrm{AE}}=0.67 \mathrm{mgCOD} /$ mgCOD. This compares well with the theoretical prediction of $\mathrm{Y}_{\mathrm{H}, \mathrm{NO}}: \mathrm{Y}_{\mathrm{H}, \mathrm{AE}}=0.83$, as well as with the average $\mathrm{Y}_{\mathrm{H}, \mathrm{NO}}=0.54$ $\mathrm{mgCOD} / \mathrm{mgCOD}\left(\mathrm{Y}_{\mathrm{H}, \mathrm{NO}}: \mathrm{Y}_{\mathrm{H}, \mathrm{AE}}=0.81 \pm 0.035\right)$ corresponding to $\mathrm{Y}_{\mathrm{H}, \mathrm{AE}}=0.67 \mathrm{mgCOD} / \mathrm{mgCOD}$, for the experimental investigations in the literature reviewed by Muller et al. (2003a).

\section{Period II: Estimation of $\mathrm{Y}_{\mathrm{H}, \mathrm{NO}}$ in Terms of $\mathrm{Y}_{\mathrm{H}, \mathrm{AE}}$ Using Wastewater RBCOD}

Similar to Period I, corresponding aerobic and anoxic batch tests were performed and $\mathrm{Y}_{\mathrm{H}, \mathrm{NO}}$ estimates determined as a function of $\mathrm{Y}_{\mathrm{H}, \mathrm{AE}}$ from the respective $\mathrm{OU}$ and $\mathrm{NU}$ measurements (Eq. [2]). The $\mathrm{Y}_{\mathrm{H}, \mathrm{NO}}$ estimates for $\mathrm{Y}_{\mathrm{H}, \mathrm{AE}}=0.67 \mathrm{mgCOD} / \mathrm{mgCOD}$ were evaluated for outliers and analysed statistically; two outliers were identified and excluded. The remaining $\mathrm{Y}_{\mathrm{H}, \mathrm{NO}}$ estimates for Period II exhibit a reasonable fit to the linear true normal line (Fig. 3), with slight deviation noticeable for larger values. The mean $\mathrm{Y}_{\mathrm{HNO}}$ of $0.563 \pm$ 0.054 (range $0.51-0.62$ ) $\mathrm{mgCOD} / \mathrm{mgCOD}$, or equivalently $\mathrm{Y}_{\mathrm{H}, \mathrm{NO}}: \mathrm{Y}_{\mathrm{H}, \mathrm{AE}}=0.84$, with respect to $\mathrm{Y}_{\mathrm{H}, \mathrm{AE}}=0.67 \mathrm{mgCOD} / \mathrm{mgCOD}$, is consistent with the theoretical $\mathrm{Y}_{\mathrm{H}, \mathrm{NO}}: \mathrm{Y}_{\mathrm{H}, \mathrm{AE}}=0.83$, the $\mathrm{Y}_{\mathrm{H}, \mathrm{NO}}: \mathrm{Y}_{\mathrm{H}, \mathrm{AE}}$ $=0.797$ determined in Period $\mathrm{I}$ and the average $\mathrm{Y}_{\mathrm{H}, \mathrm{NO}}=0.54$ $\mathrm{mgCOD} / \mathrm{mgCOD}\left(\mathrm{Y}_{\mathrm{H}, \mathrm{NO}}: \mathrm{Y}_{\mathrm{H}, \mathrm{AE}}=0.81 \pm 0.035\right)$ corresponding to $\mathrm{Y}_{\mathrm{H}, \mathrm{AE}}=0.67 \mathrm{mgCOD} / \mathrm{mgCOD}$ determined for experimental data in the literature (Muller et al., 2003a).

\section{Direct estimation of $Y_{H, A E}$ using known mass of acetate in aerobic batch tests}

In Period II, known masses of the artificial RBCOD, sodium acetate, were also added to several aerobic batch tests. From the known acetate concentration and the OU observed in its consumption, values for $\mathrm{Y}_{\mathrm{H}, \mathrm{AE}}$ were determined. One outlier was identified and excluded and the remaining data analysed statistically, Fig. 4. The data exhibit a normal distribution and give a mean $\mathrm{Y}_{\mathrm{H}, \mathrm{AE}}=$ $0.687 \pm 0.027$ (range $0.66-0.714$ ) $\mathrm{mgCOD} / \mathrm{mgCOD}$, which is in good agreement with the conventionally accepted $\mathrm{Y}_{\mathrm{H}, \mathrm{AE}}=0.67$ $\mathrm{mgCOD} / \mathrm{mgCOD}$ for domestic wastewater. This close correspondence substantiates acceptance of the standard $\mathrm{Y}_{\mathrm{H}, \mathrm{AE}}(0.67 \mathrm{mgCOD} /$ mgCOD) in this investigation.

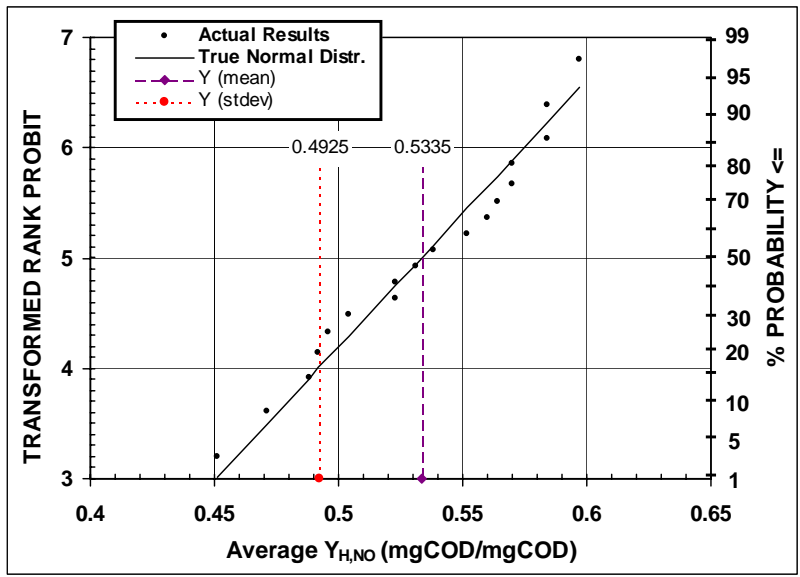

Figure 2

Period l: Statistical plot of $Y_{\text {No }}$ estimates corresponding to $Y_{H, A E}=0.67 \mathrm{mgCOD} / \mathrm{mgCOD}$ for wastewater as substrate

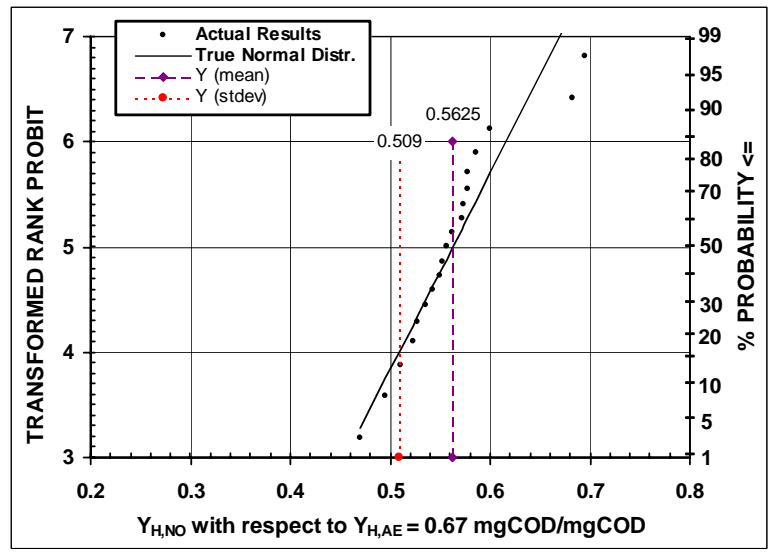

Figure 3

Period II: Statistical plot of $Y_{H, N O}$ estimates corresponding to $Y_{H, A E}=0.67 \mathrm{mgCOD} / \mathrm{mgCOD}$ for wastewater as substrate

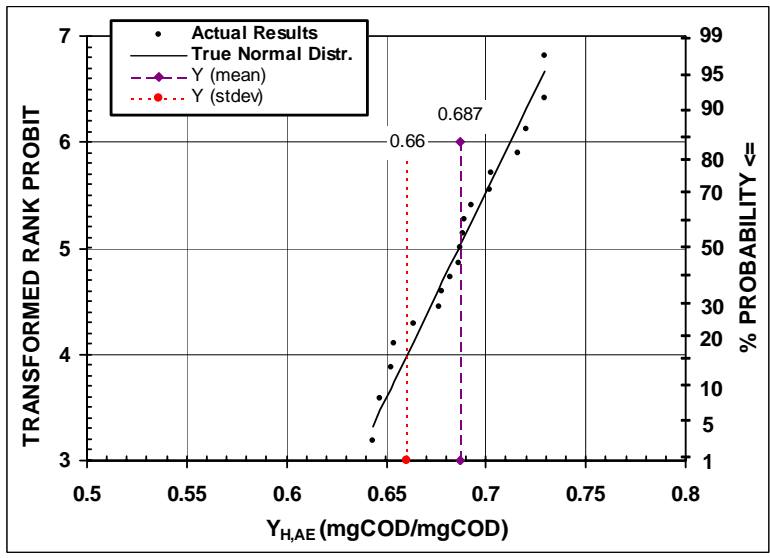

Figure 4

Period II: Statistical plot of $Y_{H, A E}$ determinations from addition of known concentration of acetate to aerobic batch tests 


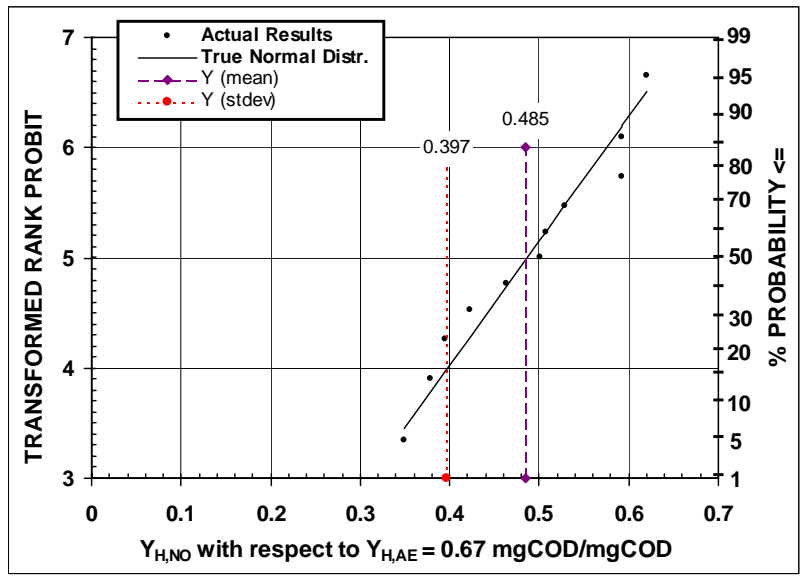

Figure 5

Period III: Statistical plot of $Y_{H, N O}$ estimates corresponding to $Y_{H, A E}=0.67 \mathrm{mgCOD} / \mathrm{mgCOD}$ for wastewater as substrate

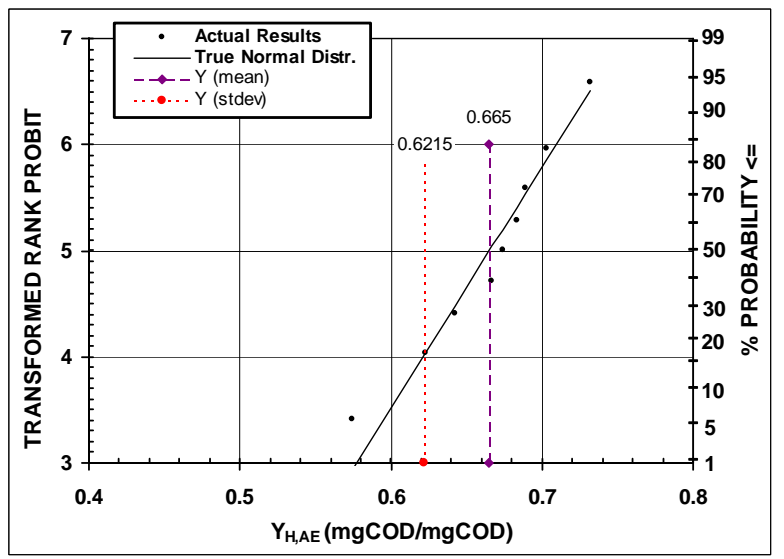

Figure 6

Period III: Statistical plot of the $Y_{H, A E}$ determinations from addition of known concentration of acetate to aerobic batch tests

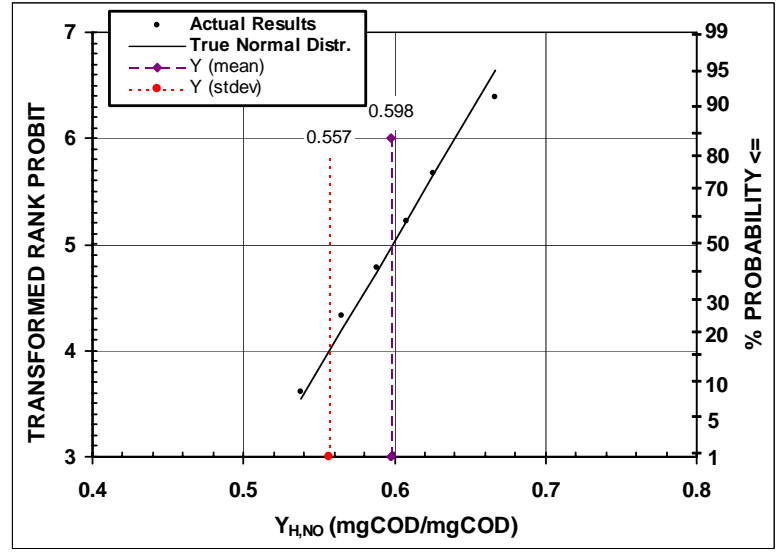

Figure 7

Period III: Statistical plot of the $Y_{H, N O}$ determinations from addition of known concentration of acetate to anoxic batch tests
Period III: Estimation of $Y_{H, N O}$ in terms of $Y_{H, A E}$ using wastewater RBCOD

As in Periods I and II, corresponding aerobic and anoxic batch tests were performed and $\mathrm{Y}_{\mathrm{H}, \mathrm{NO}}$ values determined as a function of $\mathrm{Y}_{\mathrm{H}, \mathrm{AE}}$ from the respective OU and NU measurements (Eq. [2]). The $\mathrm{Y}_{\mathrm{H}, \mathrm{NO}}$ estimates corresponding to $\mathrm{Y}_{\mathrm{H}, \mathrm{AE}}=0.67 \mathrm{mgCOD} / \mathrm{mgCOD}$ were evaluated for outliers and analysed statistically, Fig. 5. No outliers were identified, and the data exhibit a reasonable fit to the linear true normal line. The mean $\mathrm{Y}_{\mathrm{H}, \mathrm{NO}}$ of $0.485 \pm 0.088$ (range 0.397 0.573) $\mathrm{mgCOD} / \mathrm{mgCOD}$, or equivalently $\mathrm{Y}_{\mathrm{H}, \mathrm{NO}}: \mathrm{Y}_{\mathrm{H}, \mathrm{AE}}=0.724$, with respect to $\mathrm{Y}_{\mathrm{H}, \mathrm{AE}}=0.67 \mathrm{mgCOD} / \mathrm{mgCOD}$, is noticeably lower than the theoretically predicted $\mathrm{Y}_{\mathrm{H}, \mathrm{NO}}: \mathrm{Y}_{\mathrm{H}, \mathrm{AE}}=0.83$ and the values obtained in Periods I and II above. Further, both the average $\mathrm{Y}_{\mathrm{H}, \mathrm{NO}}$ and yield ratio are lower than the average $\mathrm{Y}_{\mathrm{H}, \mathrm{NO}}=0.54$ and yield ratio of $0.81 \pm 0.035$ respectively, for $\mathrm{Y}_{\mathrm{H}, \mathrm{AE}}=0.67 \mathrm{mgCOD} / \mathrm{mgCOD}$, as determined for the experimental investigations in the literature.

\section{Direct estimation of $Y_{H, A E}$ using acetate RBCOD}

As in Period II, several aerobic acetate addition batch tests were performed to estimate $Y_{\mathrm{H}, \mathrm{AE}}$ directly. The estimated values for $\mathrm{Y}_{\mathrm{H}, \mathrm{AE}}$ were evaluated for outliers and analysed statistically, Fig. 6. No outliers were identified and the data are normally distributed, giving a mean $\mathrm{Y}_{\mathrm{H}, \mathrm{AE}}$ of $0.665 \pm 0.044$ (range $0.621-0.709$ ) $\mathrm{mgCOD} / \mathrm{mgCOD}$ for utilisation of the acetate, which is in very good agreement with the value measured in Period II (0.687) and the conventionally accepted $\mathrm{Y}_{\mathrm{H}, \mathrm{AE}}=0.67 \mathrm{mgCOD} / \mathrm{mgCOD}$ for domestic wastewater ( $0.75 \%$ difference). Thus, the acceptance of the standard $\mathrm{Y}_{\mathrm{H}, \mathrm{AE}}=0.67 \mathrm{mgCOD} / \mathrm{mgCOD}$ in this study is further substantiated.

\section{Estimation of $Y_{H, N O}$ using acetate RBCOD}

Following the success achieved with acetate addition in aerobic batch tests, six anoxic (denitrification) batch tests (DBT's) were performed with the addition of known amounts of acetate to estimate $\mathrm{Y}_{\mathrm{H}, \mathrm{NO}}$ directly from the observed NU response. The acetate was added at the start of the anoxic batch tests, which contained only mixed-liquor and no wastewater. Further, the procedures for the last 4 DBT's differed; (i) DBT 40 was performed using two successive acetate additions ("a" and "b") in the same test; and (ii) DBT's $40 \mathrm{~b}$ to 42 were aerated for about 2 hours after completion of the respective anoxic acetate tests, a known mass of acetate added and an aerobic acetate batch test performed in the same reactor.

The estimated values for $\mathrm{Y}_{\mathrm{H}, \mathrm{NO}}$ were evaluated for outliers and analysed statistically, Fig. 7. No outliers were identified and the data are normally distributed giving a mean anoxic acetate $\mathrm{Y}_{\mathrm{H}, \mathrm{NO}}$ of $0.598 \pm 0.041$ (range $0.557-0.639$ ) $\mathrm{mgCOD} / \mathrm{mgCOD}$, or equivalently $\mathrm{Y}_{\mathrm{H}, \mathrm{NO}}: \mathrm{Y}_{\mathrm{H}, \mathrm{AE}}=0.893$, for $\mathrm{Y}_{\mathrm{H}, \mathrm{AE}}=0.67 \mathrm{mgCOD} / \mathrm{mgCOD}$. The yield ratio is somewhat higher than the theoretical prediction of $\mathrm{Y}_{\mathrm{H}, \mathrm{NO}}: \mathrm{Y}_{\mathrm{H}, \mathrm{AE}}=0.83$, and the directly determined $\mathrm{Y}_{\mathrm{H}, \mathrm{NO}}$ is also higher than the literature experimental average of $\mathrm{Y}_{\mathrm{H}, \mathrm{NO}}=0.54$. Interestingly, however, the average $\mathrm{Y}_{\mathrm{H}, \mathrm{AE}}=0.735 \pm 0.036 \mathrm{mgCOD} /$ mgCOD estimated from the three anoxic-aerobic acetate batch tests in which acetate was added first anoxically and then aerobically in the same test (DBT's 40b-42), is also noticeably higher than both the aerobic acetate average of $\mathrm{Y}_{\mathrm{H}, \mathrm{AE}}=0.665 \pm 0.044$ obtained previously (see above), and the accepted standard value of $\mathrm{Y}_{\mathrm{H}, \mathrm{AE}}=$ $0.67 \mathrm{mgCOD} / \mathrm{mgCOD}$. Hence, the average ratio of the two corresponding anoxic-aerobic yields obtained in the same acetate batch tests (DBT's 40b - 42), is $\mathrm{Y}_{\mathrm{H}, \mathrm{NO}}: \mathrm{Y}_{\mathrm{H}, \mathrm{AE}}=0.84 \pm 0.021$, which is in good agreement with the theoretically predicted $\mathrm{Y}_{\mathrm{H}, \mathrm{NO}}: \mathrm{Y}_{\mathrm{H}, \mathrm{AE}}=0.83$, the values determined above and the literature experimental average of 0.81 . 


\section{Average $Y_{H, N O}$ estimations using Mitchells Plain wastewater RBCOD}

By weighting the respective averages determined in Periods I to III with the corresponding number of samples $(\mathrm{N})$, a weighted average of $\mathrm{Y}_{\mathrm{H}, \mathrm{NO}}=0.534$ $\mathrm{mgCOD} / \mathrm{mgCOD}$ was determined for $\mathrm{Y}_{\mathrm{H}, \mathrm{AE}}=0.67$ $\mathrm{mgCOD} / \mathrm{mgCOD}$ for the batch tests in this study with wastewater RBCOD. In addition, experimental data from past independent research conducted in the UCT Water Research Laboratory using wastewater from the same source (i.e. MPWWTP), were re-evaluated to obtain additional $\mathrm{Y}_{\mathrm{H}, \mathrm{NO}}$ estimates (Muller et al., 2003a,b). Pooling of these estimates with the mean values obtained in this research gives an overall mean $\mathrm{Y}_{\mathrm{H}, \mathrm{NO}}$ of $0.545 \pm 0.039$ (range $0.506-0.584$ ), or equivalently $\mathrm{Y}_{\mathrm{H}, \mathrm{NO}}: \mathrm{Y}_{\mathrm{H}, \mathrm{AE}}=0.813$, for $\mathrm{Y}_{\mathrm{H}, \mathrm{AE}}=0.67$ mgCOD/mgCOD (Muller et al., 2003a). Further, on a weighted average basis, the $\mathrm{Y}_{\mathrm{H}, \mathrm{NO}}$ estimated for Mitchells Plain wastewater is $0.54 \mathrm{mgCOD} / \mathrm{mgCOD}$, or a yield ratio of $\mathrm{Y}_{\mathrm{H}, \mathrm{NO}}: \mathrm{Y}_{\mathrm{H}, \mathrm{AE}}=0.81$, for $\mathrm{Y}_{\mathrm{H}, \mathrm{AE}}=0.67$ $\mathrm{mgCOD} / \mathrm{mgCOD}$ (Table 1). This $\mathrm{Y}_{\mathrm{H}, \mathrm{NO}}$ estimate is identical to the average $\mathrm{Y}_{\mathrm{H}, \mathrm{NO}}=0.54 \mathrm{mgCOD} / \mathrm{mgCOD}$ (yield ratio $0.81 \pm 0.035)$ for $\mathrm{Y}_{\mathrm{H}, \mathrm{AE}}=0.67 \mathrm{mgCOD} / \mathrm{mgCOD}$ calculated from a wide range of experimental investigations in the literature (Muller et al., 2003a,b), and compares well with the theoretically predicted ratio of $\mathrm{Y}_{\mathrm{H}, \mathrm{NO}}: \mathrm{Y}_{\mathrm{H}, \mathrm{AE}}=0.83$.

\section{Average $Y_{H, A E}$ estimations from acetate addition}

Similarly, by weighting the respective Periods II and III $\mathrm{Y}_{\mathrm{H}, \mathrm{AE}}$ averages for the acetate aerobic batch tests, with the corresponding number of samples $(\mathrm{N})$, an overall weighted average of $\mathrm{Y}_{\mathrm{H}, \mathrm{AE}}=$ $0.680 \mathrm{mgCOD} / \mathrm{mgCOD}$ was obtained. This is remarkably close to the conventionally accepted $\mathrm{Y}_{\mathrm{H}, \mathrm{AE}}=0.67 \mathrm{mgCOD} / \mathrm{mgCOD}$. The similarity between the Periods II and III acetate $\mathrm{Y}_{\mathrm{H}, \mathrm{AE}}$ estimates suggested that the two data sets could be pooled. The pooled data was analysed statistically (Muller et al., 2003a) and gave a mean $\mathrm{Y}_{\mathrm{H}, \mathrm{AE}}$ of $0.684 \pm 0.028$ (range $0.656-0.712$ ), which is in good agreement with the conventionally accepted ("standard") $\mathrm{Y}_{\mathrm{H}, \mathrm{AE}}=$ $0.67 \mathrm{mgCOD} / \mathrm{mgCOD}$, thus substantiating acceptance of the standard $\mathrm{Y}_{\mathrm{H}, \mathrm{AE}}$ in this investigation.

\section{Average $Y_{H, N O}$ estimations from acetate addition}

Since acetate $\mathrm{Y}_{\mathrm{H}, \mathrm{NO}}$ values were only determined in Period III, all the $\mathrm{Y}_{\mathrm{H}, \mathrm{NO}}$ estimates were analysed collectively. The mean acetate $\mathrm{Y}_{\mathrm{H}, \mathrm{NO}}$ estimate is $0.598 \pm 0.041$ (range $0.557-0.639$ ) $\mathrm{mgCOD} /$ mgCOD, or equivalently $\mathrm{Y}_{\mathrm{H}, \mathrm{NO}}: \mathrm{Y}_{\mathrm{H}, \mathrm{AE}}=0.893$, for $\mathrm{Y}_{\mathrm{H}, \mathrm{AE}}=0.67$ $\mathrm{mgCOD} / \mathrm{mgCOD}$. The yield ratio is somewhat higher than the theoretical prediction of $\mathrm{Y}_{\mathrm{H}, \mathrm{NO}}: \mathrm{Y}_{\mathrm{H}, \mathrm{AE}}=0.83$, and the directly determined $Y_{H, N O}$ is also higher than the values determined with wastewater above and the literature experimental average of $\mathrm{Y}_{\mathrm{H}, \mathrm{NO}}$ $=0.54 \mathrm{mgCOD} / \mathrm{mgCOD}$. Further, the average $\mathrm{Y}_{\mathrm{H}, \mathrm{AE}}=0.735 \pm$ $0.036 \mathrm{mgCOD} / \mathrm{mgCOD}$ estimated from the three sequential anoxic-aerobic acetate batch tests (Period III) is also noticeably higher than both the aerobic acetate average $\mathrm{Y}_{\mathrm{H}, \mathrm{AE}}=0.684 \pm 0.028$ obtained above, and the accepted standard value of $\mathrm{Y}_{\mathrm{H}, \mathrm{AE}}=0.67$ $\mathrm{mgCOD} / \mathrm{mgCOD}$. Hence, for the corresponding anoxic-aerobic yields obtained within the same acetate batch tests, the average ratio is $\mathrm{Y}_{\mathrm{H}, \mathrm{NO}}: \mathrm{Y}_{\mathrm{H}, \mathrm{AE}}=0.84 \pm 0.021$, which is in good agreement with the wastewater values determined above, the theoretically predicted $\mathrm{Y}_{\mathrm{H}, \mathrm{NO}}: \mathrm{Y}_{\mathrm{H}, \mathrm{AE}}=0.83$ and the literature experimental average of 0.81 .
TABLE 1

Average (AVG) and weighted average $Y_{\mathrm{H}, \mathrm{NO}}$ estimates corresponding to $Y_{H, A E}=0.67 \mathrm{mgCOD} / \mathrm{mgCOD}$ for experimental data using Mitchells Plain sewage

\begin{tabular}{|c|c|c|c|c|}
\multirow{2}{*}{} & \multicolumn{2}{|c|}{$\begin{array}{c}\text { AVG } \mathbf{Y}_{\mathrm{H}, \mathrm{NO}} \text { Wrt }_{\mathrm{H}, \mathrm{AE}}=\mathbf{0 . 6 7} \\
\text { (mgCOD/mgCOD) }\end{array}$} & $\begin{array}{c}\text { Weighted } \\
\text { AVG }\end{array}$ \\
\cline { 2 - 4 } & AVG & SSD & $\mathbf{N}$ & \\
\hline I & 0.534 & 0.041 & 16 & 0.1335 \\
II & 0.563 & 0.054 & 19 & 0.1672 \\
III & 0.485 & 0.088 & 11 & 0.0834 \\
et al. (1991) & 0.603 & 0.05 & 4 & 0.0377 \\
et al. (1996) & 0.538 & 0.068 & 14 & 0.1177 \\
\hline L & & & $\mathbf{6 4}$ & $\mathbf{0 . 5 3 9 5}$ \\
\hline
\end{tabular}

Note: $\mathrm{AVG}=$ average; $\mathrm{SSD}=$ sample standard deviation; $\mathrm{N}=$ number of samples.

\section{Conclusions}

In this research project, the ordinary heterotrophic organism (OHO) cell yield under anoxic conditions relative to its value under aerobic conditions for municipal sewage, was investigated.

From this investigation, the following conclusions can be drawn:

- For raw wastewater from MPWWTP, a mean $\mathrm{Y}_{\mathrm{H}, \mathrm{NO}}$ of $0.534 \pm$ 0.058 was determined with respect to the conventional standard $\mathrm{Y}_{\mathrm{H}, \mathrm{AE}}$ of $0.67 \mathrm{mgCOD} / \mathrm{mgCOD}$, which gives a corresponding $\mathrm{Y}_{\mathrm{H}, \mathrm{NO}}: \mathrm{Y}_{\mathrm{H}, \mathrm{AE}}$ ratio of 0.797 . This value compares well with the theoretical ratio of $\mathrm{Y}_{\mathrm{H}, \mathrm{NO}}: \mathrm{Y}_{\mathrm{H}, \mathrm{AE}}=0.83$, as well as with the experimental average $\mathrm{Y}_{\mathrm{H}, \mathrm{NO}}: \mathrm{Y}_{\mathrm{H}, \mathrm{AE}}=0.813 \pm 0.035$ calculated for experimental data in the literature.

- Combining the above estimations with those determined from past independent research conducted in the UCT Water Research Laboratory on wastewater from the same source (i.e. the MPWWTP), a mean $\mathrm{Y}_{\mathrm{HNO}}=0.545 \pm 0.039$ (weighted average 0.54 ) with respect to $\mathrm{Y}_{\mathrm{H}, \mathrm{AE}}=0.67 \mathrm{mgCOD} / \mathrm{mgCOD}$ was obtained, which gives $\mathrm{Y}_{\mathrm{H}, \mathrm{NO}}: \mathrm{Y}_{\mathrm{H}, \mathrm{AE}}=0.813$. This latter value compares remarkably well with the theoretical ratio of 0.83 and the experimental average ratio of 0.813 calculated for data in the literature.

- For the batch tests using the artificial RBCOD, acetate, averages of $\mathrm{Y}_{\mathrm{H}, \mathrm{NO}}=0.598 \pm 0.041$ and $\mathrm{Y}_{\mathrm{H}, \mathrm{AE}}=0.687 \pm 0.027$ mgCOD/mgCOD were determined, which gives $\mathrm{Y}_{\mathrm{H}, \mathrm{NO}}: \mathrm{Y}_{\mathrm{H}, \mathrm{AE}}=$ 0.87. The average $Y_{\mathrm{H}, \mathrm{AE}}=0.687$ is in good agreement with the conventionally accepted $\mathrm{Y}_{\mathrm{H}, \mathrm{AE}}=0.67 \mathrm{mgCOD} / \mathrm{mgCOD}$, and substantiates its acceptance in this investigation. However, the average $\mathrm{Y}_{\mathrm{H}, \mathrm{NO}}$ of 0.598 is higher than the theoretically predicted $0.50 \mathrm{mgCOD} / \mathrm{mgCOD}$ and the experimental average of 0.54 $\mathrm{mgCOD} / \mathrm{mgCOD}$ calculated for data in the literature, as well as the mean $\mathrm{Y}_{\mathrm{H}, \mathrm{NO}}=0.545$ determined for Mitchells Plain wastewater above. Correspondingly, the average ratio $\mathrm{Y}_{\mathrm{H}, \mathrm{NO}}: \mathrm{Y}_{\mathrm{H}, \mathrm{AE}}=0.87$ determined for acetate, is higher than that determined for domestic sewage. However, sequential anoxic then aerobic acetate additions in the same batch test gave an average $\mathrm{Y}_{\mathrm{H}, \mathrm{NO}}: \mathrm{Y}_{\mathrm{H}, \mathrm{AE}}$ ratio of $0.84 \pm 0.021$, which is in close agreement with the values obtained above for municipal sew- 
age, and with both the theoretical and literature experimental values.

From the above, there is a remarkable consistency in the OHO yield data derived from a variety of sources. This provides substantive evidence that the $\mathrm{OHO}$ yield is reduced under anoxic conditions compared with aerobic conditions. From these investigations, it is recommended that the $\mathrm{OHO}$ anoxic yield be reduced to 0.54 $\mathrm{mgCOD} / \mathrm{mgCOD}$ with respect to an aerobic yield value of 0.67 $\mathrm{mgCOD} / \mathrm{mgCOD}$. However, in reducing the anoxic yield value in the steady-state design or kinetic simulation models, it must be remembered that the denitrification rates on slowly biodegradable (SB)COD need to be adjusted to ensure that predicted denitrification with this substrate source remains constant, since the denitrification rates are calibrated from observed denitrifications (Muller et al., 2003a).

\section{Acknowledgements}

This research was supported jointly by the Water Research Commission (WRC), National Research Foundation (NRF), Water and Sanitation Services South Africa (WSSA), Technology and Human Resources for Industry Programme (THRIP) and the University of Cape Town (UCT).

\section{References}

BARKER PS and DOLD PL (1997) General model for biological nutrient removal activated-sludge systems: Model presentation. Water Environ. Res. 69 (5) 969- 984.

BARKER PS and DOLD PL (1996) Sludge production and oxygen demand in nutrient removal activated sludge systems. Water Sci. Technol. 34 (5-6), 43-50.

CASEY TG, WENTZEL MC and EKAMA GA (1999) Filamentous organism bulking in nutrient removal activated sludge systems. Paper 10: Metabolic behaviour of heterotrophic facultative aerobic organisms under aerated/unaerated conditions. Water SA 25 (4) 425-442.

DOLD PL, EKAMA GA and MARAIS GvR (1980) A general model for the activated sludge process. Prog. Wat. Tech. 12 (Tor) 47-77.

DOLD PL, WENTZEL MC, BILLING AE, EKAMA GA and MARAIS GvR (1991) Activated sludge simulation programs: Nitrification and nitrification/denitrification systems (Version 1.0). Water Research Commission, Private Bag X03, Gezina 0031, South Africa. TT 52/91.

EKAMA GA, DOLD PL and MARAIS GvR (1986) Procedures for determining influent COD fractions and the maximum specific growth rate of heterotrophs in activated sludge systems. Water Sci. Technol. 18 (6) 91-114.

EKAMA GA, WENTZEL MC, CASEY TG and MARAIS GvR (1996) Filamentous organism bulking in nutrient removal activated sludge systems Paper 3 - Stimulation of the selector effect under anoxic conditions. Water SA 22 (2) 119-126.

GUJER W, HENZE M, MINO T and VAN LOOSDRECHT MCM (1999) Activated sludge Model No. 3. Water Sci. Technol. 39 (1) 183-193.

HENZE M, GRADY CPL (Jr), GUJER W, MARAIS GvR and MATSUO T (1987) Activated Sludge Model No. 1. IAWPRC Scientific and Technical Report No. 1, IAWPRC, London.

HENZE M, GUJER W, MINO T, MATSUO T, WENTZEL MC and MARAIS GvR (1995) Activated sludge model No.2. IAWQ Scientific and Technical Report No 3, IAWQ, London.
HENZE M, GUJER W, MINO T, MATSUO T, WENTZEL MC, MARAIS GvR and VAN LOOSDRECHT MCM (1999) Activated sludge model no. 2d. Water Sci. Technol. 39 (1) 165-182.

HU Z, WENTZEL MC and EKAMA GA (2000) External nitrification in biological nutrient removal activated sludge systems. Water SA 26 (2) 225-238.

HU Z, WENTZEL MC and EKAMA GA (2002) The significance of denitrifying polyphosphate accumulating organisms in biological nutrient removal activated sludge systems. Water Sci. Technol. 46 (12) $129-138$.

KETLEY DA, CASEY TG, EKAMA GA, WENTZEL MC and MARAIS GvR (1991) The effect of fully anoxic conditions and frequency of exposure to anoxic and aerobic conditions on the growth of low F/M filaments in nitrogen removal systems. Res. Rept. W68, Department of Civil Eng., University of Cape Town, Rondebosch 7700, South Africa.

KUBA T, SMOLDERS GJF, VAN LOOSDRECHT MCM and HEINEN JJ (1993) Biological phosphorus removal from wastewater by anaerobic-anoxic sequencing batch reactor. Water Sci. Technol. 27 (5/6) 241-252.

McCARTY PL (1971) Energetics and bacterial growth. In: Faust SD and Hunter JV (eds.) Organic Compounds in Aquatic Environments. Marcell Dekker, New York, NY, USA.

McCARTY PL (1972) Energetics of organic matter degradation. In: Mitchell R (ed.) Water Pollution Microbiology. Wiley \& Sons, New York, NY, USA.

McCARTY PL (1975) Stoichiometry of biological reactions. Prog. Wat. Tech. 7 (1) 157-172.

MULLER A, WENTZEL M and EKAMA G (2003a) Measurement of ordinary heterotroph organism anoxic yield in anoxic aerobic activated sludge systems. Res. Rept. W119, Dept. Civil Eng., Univ. Cape Town, Rondebosch 7700, South Africa.

MULLER A, WENTZEL M, LOEWENTHAL R and EKAMA G (2003b) Heterotroph anoxic yield in anoxic aerobic activated sludge systems treating municipal wastewater. Water Res. 37 2435-2441.

ORHON D, SÖZEN S and ARTAN N (1996) The effect of heterotrophic yield on the assessment of the correction factor for anoxic growth. Water Sci. Technol. 34 (5-6) 67-74.

PAYNE WJ (1981) Denitrification. John Wiley and Sons, New York.

RANDALL EW, WILKINSON A and EKAMA GA (1991) An instrument for the direct determination of oxygen utilization rate. Water SA 17 (1) 11-18.

VAN HAANDEL AC, EKAMA GA and MARAIS GvR (1981) The activated sludge process 3 - Single sludge denitrification. Water Res. 15 (10) 1135-1152.

WENTZEL MC, EKAMA GA and LOEWENTHAL RE (2003) Fundamentals of biological behaviour and wastewater strength measurement. Chapter 9 in Handbook of Water and Wastewater Microbiology, Elsivier Science Ltd, ISBN 0-12-470100-0. 131-157.

WENTZEL MC, EKAMA GA and MARAIS GvR (1992) Processes and modelling of nitrification denitrification biological excess phosphorus removal systems - A review. Water Sci. Technol. 25 (6) 59-82.

WENTZEL MC, EKAMA GA, DOLD PL and MARAIS GvR (1990) Biological excess phosphorus removal - Steady state process design. Water SA 16 (1) 29-53.

WENTZEL MC, MBEWE A, LAKAY MT and EKAMA GA (1999) Batch test for characterisation of the carbonaceous materials in municipal wastewaters. Water SA 25 (3) 327-335.

WRC (1984) Theory, Design and Operation of Nutrient Removal Activated Sludge Processes. Water Research Commission, Private Bag X03, Gezina 0031, RSA. 